\title{
The Effect of Director's Individual and Family Shareholdings on Firm Performance
}

\author{
Tsung-Che $\mathrm{Wu}^{1} \&$ Ming-hsiang Huang ${ }^{2}$ \\ ${ }^{1}$ Department of Banking and Finance, National Chiayi University, Taiwan \\ 2 Department of Business Administration, National Changhua University of Education, Taiwan \\ Correspondence: Ming-hsiang Huang, Department of Business Administration, National Changhua University of \\ Education, Taiwan.
}

Received: August 12, 2018

Accepted: August 31, 2018

Online Published: September 16, 2018

doi:10.5430/ijfr.v9n4p51

URL: https://doi.org/10.5430/ijfr.v9n4p51

\begin{abstract}
The relation between firm performance and shareholding is a critical issue in corporate governance. In this paper, we examine if significant associations exist between firm performance and (1) directors' shareholdings or (2) directors' family shareholdings among Taiwanese listed firms. After addressing for possible endogeneity and controlling for firm specific variables, we find a positive association between executive director's shareholding and firm performance. Consistent with incentive effect in agency theory, this result indicates that executive directors have incentive to maximize firms' value. Also, we find that executive directors' family shareholding is positively related to firm performance, which implies that executive directors may be motivated by their family members to improve firm value. The results also imply that the majority-minority agency problem can be mitigated when director's family welfare is at stake. In addition, we divide research sample into subsets to accommodate the effect of mandatory independent director regulation in Taiwan since 2007.
\end{abstract}

Keywords: directors' shareholding, directors' family shareholding, endogeneity

\section{Introduction}

The relation between firm performance and shareholding is a critical issue in corporate governance. In this paper, we explore the impact of directors' pecuniary interest, non-pecuniary interest, and families' shareholdings on firm performance in Taiwanese publicly listed firms. Our purpose is to examine whether there is a significant effect on the monitoring of management by directors whose financial interests are more aligned with that of shareholders by personal ownership as well as through their family. (Note 1) Taiwan is uniquely suited to this research because all directors must report the shareholding of their family members. Non-independent directors (including executive and non-executive directors) often own shares of the directed firm and register shares under the names of family members for family wealth management. (Note 2) The firm shares owned by non-independent directors' family members thus provides an opportunity to investigate how directors' family shareholdings affect firm performance.

Inclusion of directors' families' shareholdings is distinctive to the literature. The mandated disclosure of directors' family shareholdings and the regulations on independent directors announced by Taiwan Stock Exchange (TWSE) in 2001 makes the data available for our research. Starting in 2002, TWSE required all newly listed firms to hire at least two independent directors on each firm's board in order to improve quality of corporate governance in Taiwan. (Note 3) Prior corporate governance research focuses on the relationship (1) between firm performance and director/manager ownership or (2) between firm performance and founding family ownership. Our research fills a void in the current literature by analyzing (a) the effect of monetary incentives on firm performance by both non-independent directors and their families, who may motivate directors for intense monitoring, and (b) the effect of non-pecuniary interests on firm performance. The results we find among Taiwanese firms support the incentive effects found in Morck, Shleifer and Vishny (1988) and also illuminate on the agency problem between majority and minority shareholders (agency problem II) suggested by Villalonga and Amit (2006).

We examine the research questions by applying market-to-book (M/B) ratio, ROA and price-to-book $(\mathrm{P} / \mathrm{B})$ ratio as performance measures and as dependent variable in an ordinary least square (OLS) regression model, along with independent variables represent directors' (and their family members') shareholdings. In addition, we address 
possible endogeneity issues by adding the lagged value of the performance measure as a control variable (as in Opler and Titman, 1994). We also control for firm-specific variables such as non-executive directors' board seats, institutional investors' shareholdings, firm size and capital structure in our model. To our knowledge, analysis addressing endogeneity concerns and omitted firm-specific variables is a vital and distinct feature in corporate governance research.

Our result shows a significant association exists between firm performance and (1) executive (and non-executive) directors' shareholdings and (2) executive directors' family shareholdings. The positive association found between $\mathrm{M} / \mathrm{B}$ (and P/B) ratio and executive (and non-executive) directors' shareholding is consistent with incentive effect in agency theory and implies that directors have an incentive to maximize firms' value which will in turn enhance their pecuniary interest. Further, we find that executive directors' family shareholding is positively related to $\mathrm{M} / \mathrm{B}, \mathrm{P} / \mathrm{B}$, and ROA. This result indicates that executive directors can be motivated by their family members to improve firm value and thus the family welfare. However, we further find a contradicting result on the negative impact of CEO's family shareholdings on firm performance measured by ROA. This finding yields a speculation on the possible nonpecuniary interest which may override the pecuniary interest owned by CEOs and their family members.

The remainder of this essay is structured as follows. In Section 2, we review literature on (1) incentive effects, (2) board shareholdings and firm performance, (3) altruism, and (4) independent director's role of monitoring. In Section 3 , we present relevant research hypotheses. We then discuss the data and research methodology in Section 4. The results are presented in Section 5. Section 6 summarizes and concludes our research findings.

\section{Literature Review}

\subsection{Incentive Effects and Agency Problem: Ownership vs. Firm Performance}

A large body of theoretical and empirical research addresses the effect of manager/director ownership on firm performance. According to the incentive effect (Jensen and Meckling, 1976), a positive relationship exists between management ownership and firm performance. As managerial shareholding increases, the alignment of private economic interests of managers and those of shareholders increases and so managers are more likely to maximize firm value. This reduces managerial incentives to divert resources away from the firm. The alignment of managers and shareholders motivates managers to pursue higher firm values, benefiting both themselves and the other shareholders. (Note 4)

Villalonga and Amit (2006) examine the impact of family ownership/control on the firm performance to investigate the agency conflicts between majority (family) and minority (non-family) shareholders (agency problem II). They suggest that increased shares held by individual or family may (1) magnify conflicts of interest in agency problem II and thus (2) increase large shareholders' incentives for both expropriation and monitoring. (Note 5) The empirical studies regarding incentive effects in the firms are discussed in the next section.

Godfrey, Hodgson, Tarca, Hamilton, and Holmes (2010) assume the conflict of interest and information asymmetry between shareholders and management raise agency problems such as risk aversion, dividend retention, and the horizon disparity. (Note 6) The agency problems above are expected to be alleviate by bonus incentives (remuneration or shareholding) linked to firm performance, especially in longer term setting.

\subsection{Board/Management Shareholdings and Firm Value}

Empirical studies show mixed results for incentive effects. For example, Morck, Shleifer and Vishny (1988) find a non-linear relationship between director ownership and firm performance measured by Tobin's Q in Fortune 500 firms. Their results indicate a positive impact (incentive effect) on firm performance when director ownership is (1) less than $5 \%$ or (2) over $25 \%$ ownership but a negative impact (entrenchment effect) on firm performance between the 5\% to 25\% range of director ownership. In McConnell and Servaes' (1990) empirical study of U.S. firms, the results only confirms the positive relation under 5\% insider ownership. Morck, Shleifer and Vishny (1988) suggest the finding of positive impacts reflects "managers' greater incentives to maximize value as their stake rises (p.301)." For the negative impact found within the 5\% to 25\% ownership range, Morck, Shleifer and Vishny (1988) suggest that "the incentive effect can still be operative; it is just dominated by the entrenchment effect (p.302)." Morck, Shleifer and Vishny (1988) also suggest the directors, excluding top officers, are capable of becoming entrenched since those directors are less likely to have the corporate perquisites typical of top officers. (Note 7) The entrenchment opportunity, which may destroy corporate wealth, can be embedded in corporate projects desired by the board but not necessarily by the market.

Mixed results found regarding the impact of managerial shareholding on firm performance as well. For example, Hermalin and Weisbach (1988) find a positive effect when shareholding is (1) less than 1\% or (2) between 5\% and 
$20 \%$ and a negative effect when shareholding is (1) between $1 \%$ and $5 \%$ or (2) over $20 \%$. Both Lee, Rosenstein, Rangan and Davidson III (1992) and Chen and Steiner (1999) find that increased managerial ownership is related to decreased manager-shareholder agency costs, implying a positive effect on firm value. However, Demsetz and Villalonga (2001) find no relation between ownership structure and firm performance measured by Tobin's Q. They suggest the lack of significant results may be due to (1) the endogeneity of ownership or (2) the measure of ownership structure or firm performance. (Note 8)

Gul, Kim, and Qiu (2010) investigate the effect of largest-shareholder ownership concentration on stock price synchronicity of Chinese listed firms during the 1996-2003 period. They find a concave relationship with maximum at approximately 50\% ownership level. Chan and Chan (2014) find a negative relation between stock return synchronicity and SEO discounts. However, the negative relation due to information asymmetry can be mitigated by analyst coverage.

La porta, et al. (1999) and Claessens, et al. (2002) indicate the negative impact of entrenchment effect that major (controlling) shareholders have control right over cash flow right through cross-holdings or pyramid ownership mechanism. To avoid the expropriation of the non-controlling shareholders, Fan and Wong (2002) and Villalonga and Amit (2006) suggest that more shareholding will help to align major (or controlling) shareholders' wealth and firm value, thus alleviate the cost of expropriation.

Boubaker, Mansali, and Rjiba (2014) examine the effect of concentrated cash flow rights and separation of voting and cash flow rights on stock price synchronicity. The results indicate that although controlling shareholders tend to disclose less firm-specific information, when their cash flow ownership is significant, they have less incentive to adopt poor disclosure policies which may increase the risk of stock price crash. The high cash flow right thus aligns controlling shareholders' monetary interests with those of minority investors.

\subsection{Altruism and Firm Value}

Khan, Hossain, and Siddiqui (2011) suggest that family ownership can provide effective supervision on management, on a monetary interest perspective. On the other hand, the theory of altruism is first described in Becker (1974) who suggests that (1) a family head, to maximize family income, will consider the effect of personal actions on total family income and (2) family members "are motivated to maximize family income and consumption ... (p.1080)." Schulze, Lubatkin and Dino (2003) posit the efforts, among family members, to maximize one's own utility "allow the individual to simultaneously satisfy both altruistic and egoistic preference (p.475)." In family firm research, Chrisman, Chua and Litz (2004) suggest that altruism can have offsetting impacts on the firm. For example, reciprocal and symmetrical altruism can mitigate agency problems (Chrisman, Chua and Sharma, 2005), lead to more cost effectiveness, and increase value for family firms (Carney, 2005). Therefore directors' altruism toward minority family shareholdings can only benefit the firm by reducing their propensity to extract private interests from minority shareholders. This is in contrast to altruism on the part of family owners toward family managers where the latter may respond by free riding, shirking, or the consumption of perquisites because of a lack of monitoring or enforcement (Schulze, Lubatkin and Dino, 2003).

\subsection{Independent Director's Reputation: Firm Performance and Motivation}

The concept of director reputation as a motivating factor for monitoring managers can be traced to Watts and Zimmerman's working paper in 1978 and the published version in 1983 regarding the evolution of independent outside auditors. (Note 9) Watts and Zimmerman suggest that outside auditors are disciplined by the market. To preserve their reputation, outside auditors, via high quality audits, will prevent management's expropriation of shareholder wealth. Fama and Jensen (1983) suggest that outside directors can prevent collusive arrangements between managers and be regarded as professional referees among managers. Fama (1980) speculates that '... like the professional outside director, the welfare of the outside auditor depends largely on "reputation"...' (Note 10)

According to Fama and Jensen (1983), Lorsch and MacIver (1989) and Srinivasan (2005), outside directors may expect benefits from their directorship such as learning, networking opportunities and prestige. Based on survey research by Lorsch and MacIver (1989), the indirect (non-pecuniary) rewards seem to be more important to directors than the direct financial incentives. If the directed firm performed poorly, directors tended to bear the consequences which reflect negatively on either their reputation or even directorships in other firms. (Note 11)

\section{Research Hypotheses}

\subsection{Shareholdings of Non-independent Directors and Their Family Members}

For Taiwanese firms, ownership is often concentrated in a small number of large shareholders such as directors, 
CEOs, and chairmen of the board. (Note 12) Thus, the impact of poor firm performance is expected to affect both directors' and their relatives' personal wealth. According to agency theory and the theory of altruism, we expect the shares owned by non-independent directors' family members (1) align those family members' pecuniary interests with shareholders' and (2) motivate directors to monitor management to improve firm performance.

In the first and second hypothesis, we expect to find a positive relation between firm performance and shares owned by (1) non-independent directors, including CEO, executive directors, and non-executive directors, and by (2) non-independent directors' family members. In the third hypothesis, we expect the impact of directors' family shareholdings on firm performance is greater than that of directors' shareholdings. The stronger impact of family influence can be a result of either altruism (to maximize family's total welfare, including pecuniary and non-pecuniary benefits such as reputation) or monetary interest (to increase monitoring to improve firm value, based on agency theory). Although directors' family members do not sit on the board and thus are not in a direct monitoring position, directors, based on their altruism toward family members, will be motivated to monitor to improve firm value. We expect that altruism for family wellbeing will have the similar influence on firm performance as family's demands for intense monitoring do.

H1: The proportion of shares owned by non-independent directors is positively related to firm performance.

H2: The proportion of shares owned by non-independent directors' family members is positively related to firm performance.

H3: The impact of directors' family shareholdings on firm performance is greater than the impact of directors' shareholdings (possibly altruism or monetary interest).

\subsection{Independent Directors: Reputation and Monitoring}

Firms recruit independent directors for their potential contribution in reputation, expertise in the business, or social connections. The professional background of independent directors can benefit the firm and provide non-pecuniary motivation for careful monitoring when the independent directors' reputation is at stake. We assume that since wealth (such as shareholding or retainers) is restricted, reputation (or prestige) tends to dominate Taiwanese independent directors' monitoring motivations. Reputation penalties for independent directors, e.g. loss of prestige or credibility, can be a serious concern if the firm performs poorly.

In the fourth hypothesis, we expect that independent directors' non-pecuniary motivation is at least as strong as non-independent directors' pecuniary motivation. We expect to see that firm performance does not decline when the proportion of independent directors on the board increases. The result, if significant, can be used to illuminate TWSE's regulatory requirements on appointing independent directors to improve corporate governance in Taiwan. (Note 13) Thus, we expect to find a positive association between firm performance and the proportion of board seats held by independent directors in the fourth hypothesis.

H4: The proportion of independent directors on the board is positively related to firm performance in Taiwanese firms.

\section{Data and Research Method}

\subsection{Data}

The sample in this study consists of year-end fiscal data for publicly listed companies in Taiwan from 2002 to 2016. Data of directors' shareholding and that of their family members is collected from the Taiwan Economic Journal (TEJ) database and from the Market Observation Post System (MOPS) website provided by Taiwan Stock Exchange (TWSE). Other company-specific data during the same sampling period, including firm accounting information, board size, and firm performance measures, are collected from the TEJ database. We focus on the individual directors and exclude the directors representing institutional investors in the dataset. In Table 1, after matching the shareholding data with board and performance data, we present descriptive statistics of variables in three subset samples in accordance with time periods of mandatory recruitment of independent directors: (1) 2002 to 2016, (2) 2007 to 2016, and (3) 2011 to 2016. (Note 14)

Table 1. Summary statistics

\begin{tabular}{lllll}
\hline $2002 \sim 2016$ \\
$\underline{\mathbf{N}}$ & $\underline{\text { Mean }}$ & Med. & $\underline{\text { S.D. }} \quad \underline{\text { Min }} \quad \underline{\text { Max }}$
\end{tabular}




\begin{tabular}{lllllll} 
CEODSHR\% & 2182 & 0.37 & 0.03 & 1.15 & 0.00 & 11.98 \\
EXCDSHR\% & 2182 & 2.14 & 0.88 & 3.24 & 0.00 & 41.58 \\
NEXCDSHR\% & 2182 & 3.22 & 1.72 & 4.16 & 0.00 & 29.22 \\
CEODFSHR\% & 2182 & 0.14 & 0.00 & 0.70 & 0.00 & 13.56 \\
EXCDFSHR\% & 2182 & 0.75 & 0.05 & 3.77 & 0.00 & 52.89 \\
NEXCDFSHR\% & 2182 & 1.19 & 0.10 & 2.66 & 0.00 & 16.36 \\
IDDSeat\% & 2182 & 0.19 & 0.22 & 0.18 & 0.00 & 0.75 \\
NEXCDSeat\% & 2182 & 90.47 & 100.00 & 12.95 & 20.00 & 100.00 \\
IDDSeat\# & 2182 & 1.48 & 2.00 & 1.46 & 0.00 & 6.00 \\
NEXCDSeat\# & 2182 & 6.85 & 6.00 & 2.68 & 0.00 & 20.00 \\
OutInstSHR\% & 2182 & 11.10 & 8.38 & 10.48 & 0.00 & 74.01 \\
LnTA & 2182 & 16.23 & 15.96 & 1.70 & 11.78 & 21.36 \\
TDtoTA & 2182 & 42.26 & 43.25 & 18.24 & 2.27 & 98.72 \\
MB & 2182 & 1.36 & 1.13 & 0.72 & 0.49 & 7.72 \\
LagMB & 2182 & 1.73 & 1.64 & 0.97 & 0.61 & 7.72 \\
PB & 2182 & 1.58 & 1.26 & 1.20 & 0.00 & 15.15 \\
LagPB & 2182 & 2.07 & 1.98 & 1.50 & 0.16 & 13.94 \\
ROA & 2182 & 10.24 & 9.41 & 8.97 & -62.39 & 51.90 \\
LagROA & 2182 & 15.45 & 17.64 & 8.67 & -16.84 & 49.75 \\
\hline
\end{tabular}

Mean and median significance levels are obtained from $\mathrm{T}$ test and Univeariate test, respectively.

Table 1. Summary statistics (continued)

\begin{tabular}{|c|c|c|c|c|c|c|c|c|c|c|c|c|}
\hline & \multicolumn{6}{|c|}{ 2007 2016 } & \multicolumn{6}{|c|}{ 2011 2016 } \\
\hline & $\underline{\mathbf{N}}$ & $\underline{\text { Mean }}$ & $\underline{\text { Med. }}$ & $\underline{\text { S.D. }}$ & $\underline{\text { Min }}$ & $\underline{\text { Max }}$ & $\underline{\mathbf{N}}$ & $\frac{\text { Mea }}{\underline{\mathbf{n}}}$ & $\underline{\text { Med. }}$ & $\underline{\text { S.D. }}$ & $\underline{\text { Min }}$ & $\underline{\text { Max }}$ \\
\hline $\begin{array}{l}\text { CEODSHR } \\
\%\end{array}$ & 1714 & 0.34 & 0.02 & 1.13 & 0.00 & 11.98 & 1245 & 0.34 & 0.01 & 1.24 & 0.00 & 11.98 \\
\hline EXCDSHR\% & 1714 & 1.93 & 0.81 & 2.39 & 0.00 & 16.70 & 1245 & 2.05 & 1.16 & 2.44 & 0.00 & 16.70 \\
\hline $\begin{array}{l}\text { NEXCDSHR } \\
\%\end{array}$ & 1714 & 2.77 & 1.35 & 3.79 & 0.00 & 29.22 & 1245 & 2.58 & 1.00 & 3.76 & 0.00 & 22.13 \\
\hline $\begin{array}{l}\text { CEODFSHR } \\
\%\end{array}$ & 1714 & 0.13 & 0.00 & 0.70 & 0.00 & 13.56 & 1245 & 0.11 & 0.00 & 0.69 & 0.00 & 13.56 \\
\hline $\begin{array}{l}\text { EXCDFSHR } \\
\%\end{array}$ & 1714 & 0.46 & 0.05 & 1.06 & 0.00 & 7.08 & 1245 & 0.51 & 0.03 & 1.12 & 0.00 & 7.08 \\
\hline $\begin{array}{l}\text { NEXCDFSH } \\
\text { R\% }\end{array}$ & 1714 & 1.17 & 0.10 & 2.69 & 0.00 & 16.36 & 1245 & 1.05 & 0.03 & 2.50 & 0.00 & 16.36 \\
\hline IDDSeat \% & 1714 & 0.21 & 0.25 & 0.18 & 0.00 & 0.75 & 1245 & 0.23 & 0.29 & 0.17 & 0.00 & 0.63 \\
\hline $\begin{array}{l}\text { NEXCDSeat } \\
\%\end{array}$ & 1714 & 90.20 & $\begin{array}{l}100.0 \\
0\end{array}$ & 12.82 & 20.00 & $\begin{array}{l}100.0 \\
0\end{array}$ & 1245 & 89.45 & 92.31 & $\begin{array}{l}12.9 \\
5\end{array}$ & 20.00 & 100.00 \\
\hline IDDSeat\# & 1714 & 1.70 & 2.00 & 1.49 & 0.00 & 6.00 & 1245 & 1.96 & 2.00 & 1.53 & 0.00 & 5.00 \\
\hline NEXCDSeat\# & 1714 & 7.04 & 7.00 & 2.65 & 1.00 & 20.00 & 1245 & 7.30 & 7.00 & 2.75 & 1.00 & 20.00 \\
\hline $\begin{array}{l}\text { OutInstSHR } \\
\%\end{array}$ & 1714 & 11.97 & 9.27 & 10.77 & 0.00 & 74.01 & 1245 & 13.12 & 10.22 & $\begin{array}{l}11.2 \\
2\end{array}$ & 0.00 & 74.01 \\
\hline LnTA & 1714 & 16.43 & 16.07 & 1.73 & 11.78 & 21.36 & 1245 & 16.69 & 16.31 & 1.85 & 11.78 & 21.36 \\
\hline
\end{tabular}




\begin{tabular}{lcccccccccccc} 
TDtoTA & 1714 & 40.86 & 41.76 & 18.15 & 4.24 & 98.05 & 1245 & 40.01 & 41.29 & 18.0 & 4.74 & 91.03 \\
MB & 1714 & 1.40 & 1.15 & 0.74 & 0.49 & 7.72 & 1245 & 1.39 & 1.15 & 0.72 & 0.54 & 7.07 \\
LagMB & 1714 & 1.79 & 1.81 & 0.98 & 0.61 & 7.72 & 1245 & 1.77 & 1.81 & 0.89 & 0.61 & 7.29 \\
PB & 1714 & 1.65 & 1.32 & 1.24 & 0.22 & 15.15 & 1245 & 1.65 & 1.33 & 1.24 & 0.22 & 15.15 \\
LagPB & 1714 & 2.15 & 1.99 & 1.52 & 0.27 & 13.94 & 1245 & 2.13 & 2.00 & 1.44 & 0.34 & 13.94 \\
ROA & 1714 & 10.46 & 9.82 & 8.75 & -50.10 & 41.88 & 1245 & 10.32 & 9.57 & 8.72 & -50.1 & 39.57 \\
LagROA & 1714 & 16.21 & 18.18 & 7.94 & -15.85 & 49.75 & 1245 & 16.32 & 18.18 & 7.48 & -7.06 & 49.75 \\
\hline
\end{tabular}

Mean and median significance levels are obtained from $\mathrm{T}$ test and Univeariate test, respectively.

\subsection{Model}

We combine each group of independent variables and apply OLS regression model to test hypotheses. For firm performance, we use the market-to-book ratio $(\mathrm{M} / \mathrm{B})$, price-to-book ratio $(\mathrm{P} / \mathrm{B})$ and $\mathrm{ROA}$ as dependent variable in each model. The reasons to adopt $\mathrm{M} / \mathrm{B}$ ratio as performance measure are partly to be in line with that in previous literature and partly to represent market investors' perception of firm value. (Note 15) The market-to-book ratio $(\mathrm{M} / \mathrm{B})$ is defined as:

$$
\frac{\text { MarketValue }(\text { Equities })+\text { BookValue }(\text { Debts }+ \text { preferredStock })}{\text { BookValue }(\text { Assets })}
$$

The independent variables in the model consist of percentage of shares owned by CEO, executive directors, non-executive directors, percentage of shares owned by the above directors' family members, and the percentage of board seats held by independent directors. For control variables, we include the percentage of board seats held by non-executive directors (to proxy for omitted variables affecting the percentage of independent directors on the board (Note 16)), percentage of shares owned by outside institutions, the log term of total assets, the ratio of total debts to total assets, and the lag one term of performance measure (to address possible endogeneity issues. (Note 17)) The model for our examination is:

$$
\begin{aligned}
& \text { FirmPerformance }=\alpha+\beta_{1} \% \text { ShareByCEODir }+\beta_{2} \% \text { ShareByExe cDir } \\
& +\beta_{3} \% \text { ShareByNonExecDir }+\beta_{4} \% \text { ShareByCEODir' sFamily } \\
& +\beta_{5} \% \text { ShareByExe cDir' sFamily }+\beta_{6} \% \text { ShareByNonExecDir' sFamily } \\
& +\beta_{7} \% \text { SeatByIndepDir }+\beta_{8} \% \text { SeatByNonExecDir } \\
& +\beta_{9} \% \text { ShareByInstitution }+\beta_{10} \text { Ln }(\text { TotalAssets })+\beta_{11} \text { Debt / Asset } \\
& +\beta_{12} \text { LagPerformance }+\varepsilon
\end{aligned}
$$

For a further examination in the third hypothesis, we replace the percentage of board seats held by independent and by non-executive directors with the number of board seats held by those directors. The purpose of this test is to check if results are consistent by providing alternative measurements (absolute term via percentages vs. relative term via numbers). The alternative model is:

$$
\begin{aligned}
& \text { FirmPerformance }=\alpha+\beta_{1} \% \text { ShareByCEODir }+\beta_{2} \% \text { ShareByExecDir } \\
& +\beta_{3} \% \text { ShareByNonExecDir }+\beta_{4} \% \text { ShareByCEODir' sFamily } \\
& +\beta_{5} \% \text { ShareByExe cDir' sFamily }+\beta_{6} \% \text { ShareByNonExecDir' sFamily } \\
& +\beta_{7} \# \text { SeatByIndepDir }+\beta_{8} \# \text { SeatByNonExecDir } \\
& \left.+\beta_{9} \% \text { ShareByInstitution }+\beta_{10} \text { Ln(TotalAssets }\right)+\beta_{11} \text { Debt / Asset } \\
& +\beta_{12} \text { LagPerformance }+\varepsilon,
\end{aligned}
$$

\section{Results}

In Table 2 and Table 3, we test the first and second hypothesis with dataset period ranging from 2002 to 2016 and 
then with dataset period of 2007-16 and 2011-16. For firm shares owned by executive directors, we find a positive and significant association between M/B (also P/B) and executive directors' shareholdings in all datasets. However, for non-executive directors' shareholding, positive and significant association between $\mathrm{M} / \mathrm{B}$ (also $\mathrm{P} / \mathrm{B}$ ) and non-executive directors' shareholdings is found with 2007-16 dataset. Consistent with agency theory, the results imply that executive and non-executive directors have influence on firms' operations and have an incentive to maximize firm value which will enhance their pecuniary interest. Also, the mean shareholding of executive directors $(2.14 \%, 1.93 \%$ and $2.05 \%$ as in Table 1) falls within the ownership range (0\% to 5\%) that Morck, Shleifer and Vishny (1988) suggest the incentive effect occurs. Thus, the positive effect of executive directors' shareholding on firm performance found in Taiwanese firms is consistent with incentive effects in agency theory.

For the third hypothesis, we expect that, due to altruism or monitoring, the impact of directors' family's shareholding on firm performance is greater than that of directors' shareholdings. This hypothesis is supported with the evidence that executive directors' family shareholdings have a larger (and positive) association with firm performance than executive directors do, (Note 18) implying that executive directors may be motivated by their family members to improve firm value. The result also implies that having (directors') family members' ownership may reduce the agency problem II because executive directors are less likely to expropriate private benefits at the expense of minority shareholders when directors' family benefit is involved. Even when executive directors' family members own relatively fewer shares than those executive directors do, (Note 19) the expropriation of minority shareholders' interest (such as the agency problem II in Villalonga and Amit (2006)) would be reduced as long as the family welfare is at stake.

However, we further find a mixed and contradicting result on CEO's family shareholding. A negative association is found between ROA and CEO's family shareholding for 2007-16 and 2011-16 period. But positive association between M/B (also P/B) and CEO's family shareholding is found for 2011-16 period. This mixed finding yields a speculation on the possible non-monetary interest which may override the monetary interest owned by CEOs and their family members. A further study in the future with various examination is expected for this intermingled result.

For the fourth hypothesis, based on agency theory, we expect a positive association between the proportion of independent directors on board and firm performance. We expect to find evidence among Taiwanese publicly listed firms to support Fama and Jensen's (1983) suggestion on independent director's role of monitoring. Unfortunately, no significant association has been found in 2007-2016 or 2011-2016 period. Whether the mandatory recruitment of independent directors on board since 2007 has yielded a regulation compliance motivation which is prevails the suggested monitoring motivation is also merits profounder studies in the future.

Table 2. Regression results of Model 1 for 2002-16, 2007-16, and 2011-16 periods

\begin{tabular}{|c|c|c|c|c|c|c|c|c|c|}
\hline & \multicolumn{3}{|c|}{$2002 \sim 2016$} & \multicolumn{3}{|c|}{$2007 \sim 2016$} & \multicolumn{3}{|c|}{$2011 \sim 2016$} \\
\hline & $\underline{\mathbf{M} / \mathbf{B}}$ & $\underline{\mathbf{P} / \mathbf{B}}$ & $\underline{\text { ROA }}$ & $\underline{\mathbf{M} / \mathbf{B}}$ & $\underline{\mathbf{P} / \mathbf{B}}$ & $\underline{\text { ROA }}$ & $\underline{\mathbf{M} / \mathbf{B}}$ & $\underline{\mathbf{P} / \mathbf{B}}$ & $\underline{\text { ROA }}$ \\
\hline \multirow[t]{2}{*}{ Intercept } & -0.6240 & -0.9834 & -8.6573 & -0.5477 & -1.0847 & -8.1071 & -0.1850 & 0.0033 & 5.5069 \\
\hline & -0.44 & -0.47 & -1.02 & -0.37 & -0.49 & -0.91 & -0.13 & 0 & 0.57 \\
\hline \multirow[t]{2}{*}{ CEODSHR \% } & -0.1999 & -0.3356 & -0.3859 & -0.2008 & -0.3393 & 0.3882 & -0.2016 & -0.3999 & -1.2071 \\
\hline & -1.13 & -1.27 & -0.6 & -1.1 & -1.24 & 0.55 & -1.16 & -1.32 & -1.08 \\
\hline \multirow[t]{2}{*}{ EXCDSHR\% } & 0.1401 & 0.2216 & 0.0402 & 0.2145 & 0.3354 & -0.1238 & 0.1277 & 0.2330 & -0.0063 \\
\hline & $2.5 * *$ & $2.65 * * *$ & 0.15 & $3.05 * * *$ & $3.16^{* * *}$ & -0.41 & $2.2 * *$ & $2.35^{* *}$ & -0.02 \\
\hline \multirow[t]{2}{*}{ NEXCDSHR\% } & 0.0574 & 0.0402 & 0.5156 & 0.1037 & 0.1010 & 0.3721 & 0.0537 & 0.0463 & 0.3017 \\
\hline & 1.61 & 0.76 & $2.43 * *$ & $2.57 * *$ & $1.67 *$ & 1.54 & 1.6 & 0.8 & 1.38 \\
\hline \multirow[t]{2}{*}{ CEODFSHR\% } & 0.2909 & 0.4405 & -0.2587 & 0.2862 & 0.4408 & -1.1634 & 0.6914 & 1.2165 & -0.7944 \\
\hline & 1.28 & 1.3 & -0.71 & 1.24 & 1.27 & $-2.17 * *$ & $2.03 * *$ & $2.04 * *$ & -1.46 \\
\hline \multirow[t]{2}{*}{ EXCDFSHR\% } & 0.3030 & 0.4332 & -0.0177 & 0.2897 & 0.4110 & 1.9857 & 0.0698 & 0.1331 & 0.7912 \\
\hline & $3.1 * * *$ & $3.01 * * *$ & -0.11 & $2.94 * * *$ & $2.81 * * *$ & $2.25^{* *}$ & 0.85 & 0.95 & 0.84 \\
\hline \multirow[t]{2}{*}{ NEXCDFSHR\% } & -0.0643 & 0.0399 & 0.0812 & -0.1265 & -0.0375 & 0.2083 & -0.1749 & -0.0677 & -0.4904 \\
\hline & -0.82 & 0.34 & 0.17 & -1.53 & -0.3 & 0.42 & $-2.17 * *$ & -0.47 & -0.89 \\
\hline
\end{tabular}




\begin{tabular}{llllllllll} 
IDDSeat\% & 0.3390 & 0.1618 & 0.9205 & 0.4497 & 0.3317 & 1.3766 & -0.2383 & -0.3917 & -2.7298 \\
& 0.53 & 0.17 & 0.22 & 0.66 & 0.33 & 0.31 & -0.42 & -0.39 & -0.64 \\
NEXCDSeat\% & 0.0040 & 0.0060 & -0.0738 & 0.0068 & 0.0111 & -0.0276 & 0.0017 & 0.0024 & -0.0336 \\
& 0.55 & 0.54 & $-1.79 *$ & 0.85 & 0.92 & -0.54 & 0.24 & 0.2 & -0.65 \\
OutInstSHR\% & 0.0167 & 0.0215 & 0.0890 & 0.0195 & 0.0237 & 0.1147 & 0.0127 & 0.0173 & 0.0923 \\
& $1.69 *$ & 1.46 & 1.38 & $1.77 *$ & 1.44 & 1.56 & 1.35 & 1.06 & 1.22 \\
LnTA & 0.0434 & 0.0463 & 1.1828 & 0.0351 & 0.0366 & 1.0140 & 0.0252 & 0.0284 & 0.1616 \\
& 0.53 & 0.38 & $2.28^{* *}$ & 0.42 & 0.29 & $1.87 *$ & 0.34 & 0.22 & 0.3 \\
TDtoTA & -0.0065 & -0.0041 & -0.0515 & -0.0123 & -0.0107 & -0.0659 & -0.0083 & -0.0142 & -0.0900 \\
& -1.05 & -0.47 & -1.42 & $-1.85 *$ & -1.15 & $-1.67 *$ & -1.43 & -1.47 & $-2.21^{* *}$ \\
LagPerform. & 0.4557 & 0.4922 & 0.5490 & 0.3905 & 0.4330 & 0.4439 & 0.7489 & 0.6619 & 0.7470 \\
& $6.17 * * *$ & $6.75 * * *$ & $8.09 * * *$ & $5 * * *$ & $5.54 * * *$ & $5.09 * * *$ & $9.12 * * *$ & $7.01 * * *$ & $7.68 * * *$ \\
& & & & & & & & & \\
Obs. & 2182 & 2182 & 2182 & 1714 & 1714 & 1714 & 1245 & 1245 & 1245 \\
Adj. R-Sq & 0.5965 & 0.6196 & 0.5379 & 0.6182 & 0.6338 & 0.5320 & 0.8189 & 0.7744 & 0.7273 \\
\hline
\end{tabular}

$\mathrm{t}$-value is presented in Italic fonts below each coefficient estimate.

Subscript $* * * * *$, and $*$ denotes statistical significance at the $1 \%, 5 \%$, and $10 \%$ levels, respectively.

The percentage of board seats held by independent (IDDSeat $\%$ ) and by non-executive directors (NEXCDSeat $\%$ ) are applied in this model.

Table 3. Regression results of Model 2 for 2002-16, 2007-16, and 2011-16 periods

\begin{tabular}{lllllll|lll}
\hline & $\mathbf{2 0 0 2} \mathbf{2 0 1 6}$ & \multicolumn{3}{c}{$\mathbf{2 0 0 7} \mathbf{2 0 1 6}$} & \multicolumn{3}{c}{$\mathbf{2 0 1 1 ~ 2 0 1 6}$} \\
\hline & $\underline{\mathbf{M} / \mathbf{B}}$ & $\underline{\mathbf{P} / \mathbf{B}}$ & $\underline{\mathbf{R O A}}$ & $\underline{\mathbf{M} / \mathbf{B}}$ & $\underline{\mathbf{P} / \mathbf{B}}$ & $\underline{\mathbf{R O A}}$ & $\underline{\mathbf{M} / \mathbf{B}}$ & $\underline{\mathbf{P} / \mathbf{B}}$ & $\underline{\mathbf{R O A}}$ \\
Intercept & & & & & & & & & \\
& -0.3358 & -0.5800 & -15.6299 & 0.0072 & -0.2139 & -10.1613 & -0.0166 & 0.2573 & 1.5872 \\
CEODSHR\% & -0.26 & -0.31 & $-1.98 * *$ & 0.01 & -0.11 & -1.25 & -0.01 & 0.12 & 0.18 \\
& -0.1534 & -0.2482 & -0.3878 & -0.1524 & -0.2382 & 0.5657 & -0.2422 & -0.4672 & -1.2160 \\
EXCDSHR\% & -0.85 & -0.92 & -0.59 & -0.82 & -0.86 & 0.8 & -1.3 & -1.44 & -1 \\
& 0.1445 & 0.2372 & 0.1912 & 0.2096 & 0.3413 & -0.0359 & 0.1032 & 0.1918 & 0.0396 \\
NEXCDSHR\% & $2.62 * * *$ & $2.9 * * *$ & 0.71 & $3.16^{* * *}$ & $3.43 * * *$ & -0.12 & $1.83 *$ & $1.97 *$ & 0.12 \\
& 0.0543 & 0.0414 & 0.5196 & 0.0994 & 0.1036 & 0.3424 & 0.0463 & 0.0332 & 0.3029 \\
CEODFSHR\% & 1.57 & 0.81 & $2.46 * *$ & $2.54 * *$ & $1.77 *$ & 1.44 & 1.41 & 0.59 & 1.39 \\
& 0.2550 & 0.3602 & -0.2007 & 0.2507 & 0.3500 & -1.2749 & 0.7646 & 1.3314 & -0.9612 \\
EXCDFSHR\% & 1.11 & 1.05 & -0.54 & 1.07 & 1 & $-2.53 * *$ & $2.17 * *$ & $2.16^{* *}$ & $-1.90 *$ \\
& 0.2829 & 0.4143 & -0.0552 & 0.2593 & 0.3721 & 2.2617 & 0.0593 & 0.1159 & 1.1840 \\
NEXCDFSHR\% & -0.0703 & 0.0157 & -0.1171 & -0.1305 & -0.0635 & 0.0810 & -0.1312 & 0.0028 & -0.5499 \\
& -0.88 & 0.13 & -0.23 & -1.55 & -0.51 & 0.15 & -1.46 & 0.02 & -0.82 \\
IDDSeat\# & 0.0181 & 0.0165 & -0.0290 & 0.0328 & 0.0439 & -0.0174 & -0.0598 & -0.1010 & -0.3228 \\
& 0.24 & 0.15 & -0.06 & 0.42 & 0.38 & -0.03 & -0.92 & -0.89 & -0.62 \\
NEXCDSeat\# & 0.0285 & 0.0560 & 0.0999 & 0.0315 & 0.0644 & 0.1725 & -0.0090 & -0.0159 & 0.0213 \\
& 1 & 1.34 & 0.54 & 1.09 & 1.52 & 0.93 & -0.32 & -0.33 & 0.10 \\
OutInstSHR\% & 0.0203 & 0.0258 & 0.0934 & 0.0245 & 0.0301 & 0.1305 & 0.0125 & 0.0169 & 0.0878 \\
& $2.07 * *$ & $1.79 *$ & 1.45 & $2.32 * *$ & $1.92 *$ & $1.84 *$ & 1.35 & 1.05 & 1.18
\end{tabular}




\begin{tabular}{llllllllll} 
LnTA & 0.0302 & 0.0202 & 1.1839 & 0.0159 & 0.0011 & 0.9248 & 0.0338 & 0.0425 & 0.2215 \\
& 0.36 & 0.16 & $2.15 * *$ & 0.19 & 0.01 & 1.64 & 0.46 & 0.34 & 0.40 \\
TDtoTA & -0.0060 & -0.0035 & -0.0419 & -0.0116 & -0.0103 & -0.0603 & -0.0087 & -0.0147 & -0.0836 \\
& -0.96 & -0.4 & -1.14 & $-1.73^{*}$ & -1.1 & -1.52 & -1.48 & -1.51 & $-2.02^{* *}$ \\
LagPerform. & 0.4769 & 0.5035 & 0.5637 & 0.4194 & 0.4509 & 0.4464 & 0.7500 & 0.6666 & 0.7291 \\
& $6.5^{* * *}$ & $7.05^{* * *}$ & $8.1 * * *$ & $5.47^{* * *}$ & $5.99^{* * *}$ & $5.24 * * *$ & $9.55^{* * *}$ & $7.4 * * *$ & $7.77^{* * *}$ \\
& & & & & & & & & \\
Obs. & 2182 & 2182 & 2182 & 1714 & 1714 & 1714 & 1245 & 1245 & 1245 \\
Adj. R-Sq & 0.5987 & 0.6255 & 0.5241 & 0.6199 & 0.6404 & 0.5344 & 0.8209 & 0.7768 & 0.7254 \\
\hline
\end{tabular}

$\mathrm{t}$-value is presented in Italic fonts below each coefficient estimate.

Subscript $* * *, * *$, and $*$ denotes statistical significance at the $1 \%, 5 \%$, and $10 \%$ levels, respectively.

The number of board seats held by independent (IDDSeat\#) and by non-executive directors (NEXCDSeat\#) are applied in this model.

\section{Conclusion}

In this research, we explore the impact of directors' (1) pecuniary interest, (2) non-pecuniary interest and (3) their family's shareholdings on firm performance. We examine associations between firm performance and (1) directors' shareholdings, (2) directors' family shareholdings, and (3) independent directors on board among Taiwanese publicly listed firms from 2002 to 2016.

Based on the results of OLS regression model, after addressing endogeneity concern and controlling for firm-specific variables, we find a positive association between executive directors' shareholding and firm performance. The result, which is consistent with the incentive effect in agency theory suggested by Morck, Shleifer and Vishny (1988), implies executive directors have influence on firms' operations and have an incentive to maximize firms' value, in turn, enhancing their pecuniary interest. An alternative model adopting the number of seats on board yields consistent results to support this suggestion. However, we also find a negative and mixed association existed between firm performance and CEOs' family shareholdings. This finding yields a speculation, for further research, on the possible non-monetary interest which may prevail the monetary interest owned by CEOs and their family members.

For shares owned by directors' family, we find sounder and positive association between executive directors' family shareholding and firm performance. This result indicates that executive directors may behave altruistically or be motivated by family members for monitoring to improve firm value. This may also imply that having family member ownership can reduce the agency problem II, because executive directors are less likely to expropriate private benefits at the expense of minority shareholders when directors' family welfare is involved.

For independent directors on board, we failed to find evidence among Taiwanese publicly listed firms to support Fama and Jensen's (1983) suggestion on independent director's role of monitoring. Whether the mandatory independent directors on board since 2007 has yielded a regulation compliance motivation which prevails the suggested monitoring motivation is also merits profounder studies in the future.

Our research hypotheses are partially supported by significant results found with several variables. For the other variables that do not yield significant results, we can only expect further studies when profounder methods or data is available. Also, additional measures of directors' pecuniary and non- pecuniary interest, are expected for further examination concerning the impact of directors' (and their family's) interests on monitoring or firm performance.

\section{References}

Becker, G. S. (1974). A Theory of Social Interactions. Journal of Political Economy, 82, 1063-1093. https://doi.org/10.1086/260265

Boubaker, S., Mansali, H., \& Rjiba, H. (2014). Large controlling shareholders and stock price synchronicity. Journal of Banking \& Finance, 40, 80-96. https://doi.org/10.1016/j.jbankfin.2013.11.022

Carney, M. (2005). Corporate Governance and Competitive Advantage in Family-Controlled Firms. Entrepreneurship: Theory \& Practice, 29, 249-265. https://doi.org/10.1111/j.1540-6520.2005.00081.x 
Chan, K., \& Chan, Y.-C. (2014). Price informativeness and stock return synchronicity: Evidence from the pricing of seasoned equity offerings. Journal of Financial Economics, 114, 36-53. https://doi.org/10.1016/j.jfineco.2014.07.002

Chen, C. R., \& Steiner, T. L. (1999). Managerial Ownership and Agency Conflicts: A Nonlinear Simultaneous Equation Analysis of Managerial Ownership, Risk Taking, Debt Policy, and Dividend Policy. Financial Review, 34, 119. https://doi.org/10.1111/j.1540-6288.1999.tb00448.x

Chiang, H.-T. (2005). An Empirical Study of Corporate Governance and Corporate Performance. Journal of American Academy of Business, Cambridge, 6, 95-101.

Chrisman, J. J., Chua, J. H., \& Litz, R. A. (2004). Comparing the Agency Costs of Family and Non-Family Firms: Conceptual Issues and Exploratory Evidence. Entrepreneurship: Theory \& Practice, 28, 335-354. https://doi.org/10.1111/j.1540-6520.2004.00049.x

Chrisman, J. J., Chua, J. H., \& Sharma, P. (2005). Trends and Directions in the Development of a Strategic Management Theory of the Family Firm. Entrepreneurship: Theory \& Practice, 29, 555-575. https://doi.org/10.1111/j.1540-6520.2005.00098.x

Claessens, S., Djankov, S., Fan, J. P. H., \& Lang, L. H. P. (2002). Disentangling the Incentive and Entrenchment Effects of Large Shareholdings. Journal of Finance, 57, 2741-2771. https://doi.org/10.1111/1540-6261.00511

Claessens, S., Djankov, S., \& Lang, L. H. P. (2000). The Separation of Ownership and Control in East Asian Corporations. Journal of Financial Economics, 58, 81-112. https://doi.org/10.1016/S0304-405X(00)00067-2

Coughlan, A. T., \& Schmidt, R. M. (1985). Executive Compensation, Management Turnover, and Firm Performance. An Empirical Investigation. Journal of Accounting \& Economics, 7, 43-66. https://doi.org/10.1016/0165-4101(85)90027-8

Demsetz, H., \& Villalonga, B. (2001). Ownership Structure and Corporate Performance. Journal of Corporate Finance, 7, 209-233. https://doi.org/10.1016/S0929-1199(01)00020-7

Faccio, M., \& Lang, L. H. P. (2002). The Ultimate Ownership of Western European Corporations. Journal of Financial Economics, 65, 365-395. https://doi.org/10.1016/S0304-405X(02)00146-0

Fama, E. F. (1980). Agency Problems and the Theory of the Firm. Journal of Political Economy, 88, 288-307. https://doi.org/10.1086/260866

Fama, E. F., \& Jensen, M. C. (1983). Separation of Ownership and Control. Journal of Law \& Economics, 26, 301-326. https://doi.org/10.1086/467037

Fan, J., \& Wong, T. (2002). Corporate ownership structure and the informativeness of accounting earnings in East Asia. Journal of Accounting and Economics, 33, 401-425. https://doi.org/10.1016/S0165-4101(02)00047-2

Fich, E. M., \& Shivdasani, A. (2006). Are Busy Boards Effective Monitors?. Journal of Finance, 61, 689-724. https://doi.org/10.1111/j.1540-6261.2006.00852.x

Godfrey, J., Hodgson, A., Tarca, A., Hamilton, J., \& Holmes, S. (2010). Accounting Theory (7th ed.). New York: John Wiley \& Sons, Inc.

Gul, F. A., Kim, J.-B., \& Qiu, A. A. (2010). Ownership concentration, foreign shareholding, audit quality, and stock price synchronicity: Evidence from China. Journal of Financial Economics, 95, 425-442. https://doi.org/10.1016/j.jfineco.2009.11.005

Helland, E., \& Sykuta, M. (2005). Who's Monitoring the Monitor? Do Outside Directors Protect Shareholders' Interests?. Financial Review, 40, 155-172. https://doi.org/10.1111/j.1540-6288.2005.00098.x

Hermalin, B. E., \& Weisbach, M. S. (1988). The Determinants of Board Composition. RAND Journal of Economics 19, 589-606. https://doi.org/10.2307/2555459

Jensen, M. C., \& Meckling, W. H. (1976). Theory of the Firm: Managerial Behavior, Agency Costs and Ownership Structure. Journal of Financial Economics, 3, 305-360. https://doi.org/10.1016/0304-405X(76)90026-X

Keasey, K., Short, H., \& Watson, R. (1994). Directors' Ownership and the Performance of Small and Medium Sized Firms in the U.K. Small Business Economics, 6, 225-236. https://doi.org/10.1007/BF01108290

Khan, A. R., Hossain, D. M., \& Siddiqui, J. (2011). Corporate ownership concentration and audit fees: The case of an emerging economy. Advances in Accounting, 27(1), 125-131. https://doi.org/10.1016/j.adiac.2011.04.007

La porta, R., Lopez-De-Silanes, F., Shleifer, A., \& Vishny, R. (2002). Investor Protection and Corporate Valuation. 
Journal of Finance, 57, 1147. https://doi.org/10.1111/1540-6261.00457

Lee, C. I., Rosenstein, S., Rangan, N., \& Davidson, W. N. III. (1992). Board Composition and Shareholder Wealth: The Case of Management Buyouts. FM: The Journal of the Financial Management Association, 21, 58-72. https://doi.org/10.2307/3665681

Lorsch, J. L., \& MacIver, E. M. (1989). Pawns or Potentates? The Reality of America's Corporate Boards. Harvard Business School Press.

McConnell, J. J., \& Servaes, H. (1990). Additional Evidence on Equity Ownership and Corporate Value. Journal of Financial Economics, 27, 595-612. https://doi.org/10.1016/0304-405X(90)90069-C

Morck, R., Shleifer, A., \& Vishny, R.W. (1988). Management Ownership and Market Valuation: An Empirical Analysis. Journal of Financial Economics, 20, 293-315. https://doi.org/10.1016/0304-405X(88)90048-7

Opler, T. C., \& Titman, S. (1994). Financial Distress and Corporate Performance. Journal of Finance, 49, 1015-1040. https://doi.org/10.1111/j.1540-6261.1994.tb00086.x

Schulze, W. S., Lubatkin, M. H., \& Dino, R. N. (2003). Exploring the Agency Consequences of Ownership Dispersion among the Directors of Private Family Firms. Academy of Management Journal, 46, 179-194.

Schulze, W.S., Lubatkin, M. H., \& Dino, R. N. (2003). Toward a Theory of Agency and Altruism in Family Firms. Journal of Business Venturing, 18, 473. https://doi.org/10.1016/S0883-9026(03)00054-5

Shleifer, A., \& Vishny, R.W. (1997). A Survey of Corporate Governance. Journal of Finance, 52, 737-783. https://doi.org/10.1111/j.1540-6261.1997.tb04820.x

Srinivasan, S. (2005). Consequences of Financial Reporting Failure for Outside Directors: Evidence from Accounting Restatements and Audit Committee Members. Journal of Accounting Research, 43, 291-334. https://doi.org/10.1111/j.1475-679x.2005.00172.x

Villalonga, B., \& Amit, R. (2006). How Do Family Ownership, Control and Management Affect Firm Value?. Journal of Financial Economics, 80, 385-417. https://doi.org/10.1016/j.jfineco.2004.12.005

Wu, T.-C. (2009). Essays Concerning the Directors of Taiwanese Corporations: Their Turnovers and Their Influence on Firm Performance, Ph.D. Dissertation, Department of Finance and Economics, Mississippi State University, U.S.A., 70-140.

Wu, T.-C. (2011). The Effect of Directors' Shareholdings and Career Affiliations on the Performance of Taiwanese Publicly Listed Firms. The International Conference on New Global Management Environment 2011, College of Management, National Changhua University.

Yeh, Y.-H. (2005). Do Controlling Shareholders Enhance Corporate Value?. Corporate Governance, 13, 313-325. https://doi.org/10.1111/j.1467-8683.2005.00425.x

Yeh, Y.-H., Lee, T.-S., \& Woidtke, T. (2001). Family Control and Corporate Governance: Evidence from Taiwan. International Review of Finance, 2, 21. https://doi.org/10.1111/1468-2443.00014

\section{Notes}

Note 1. According to Fama (1980) and Coughlan and Schmidt (1985), monitoring management to ensure to maximize shareholders' wealth is an important job for a board of directors.

Note 2. In this paper, we classify directors in Taiwan as (1) executive directors: directors who also hold executive positions in the firm, (2) non-executive directors: directors who do not hold executive position in the directed firm, and (3) independent directors: directors who have no affiliation with the firm. We will also use the title "non-independent directors" to include both executive and non-executive directors.

Note 3. Based on Security Exchange Law, TWSE requires mandatory recruitment of independent directors for newly listed firms since 2002. For firms listed before 2002, stage-1 mandatory recruitment is applied (since 2007) for firms with market capitalization over NTD \$50 billion; stage-2 mandatory recruitment is applied (since 2011) for firms with market capitalization over NTD $\$ 10$ billion; stage-3 mandatory recruitment is applied (since 2014) for all publicly listed firms in Taiwan. (http://www.tej.com.tw/webtej/plus/wcg.files/tcgi2.files/Rules.htm)

Note 4. Keasey, Short and Watson (1994) and Chiang (2005). Besides, Shleifer and Vishny (1997) also suggest that larger shareholders use their voting power to alleviate agency problems and maximize firm value.

Note 5. Villalonga and Amit (2006) name this type of agency conflict as Agency Problem II. They find that (1) 
family ownership creates firm value only when founder is in control and (2) when descendent serves as CEO, firm value is destroyed. They also find that firm value will decrease when large (family) shareholders' control rights are larger than cashflow rights (shareholdings).

Note 6. Risk aversion problem indicates that management may be more risk averse (than shareholders) and take lower risk projects which may yield lower return. Dividend retention problem is related to management's intention to pay less dividends and to retain more for company growth which will benefit management in return. The horizon disparity problem denotes management's short-term consideration regarding company projects and performance.

Note 7. Morck, Shleifer and Vishny (1988) denote the variable OUTBOARD to represent the board members excluding the top officer directors (denoted as OFFICER, usually the chairman and the president).

Note 8 . The simultaneity between ownership structure and firm value is the main source of endogeneity problem which affects the result of value-ownership research.

Note 9. Footnote 3, p.294, Fama (1980).

Note 10. Footnote 3, p.294, Fama (1980). Fama and Jensen (1983) also speculate that outside directors, who rely more on their reputation as professionals, will have more concerns regarding potential reputation penalties due to poor firm performance.

Note 11. Fama (1980); Fich and Shivdasani (2006); and Srinivasan (2005).

Note 12. Claessens, Djankov and Lang (2000); Yeh, Lee and Woidtke (2001).

Note 13. In the U.S. firms, Helland and Sykuta (2005) find that U.S. companies with more outside directors are less likely to be targets of shareholder litigation. They suggest that boards with higher proportions of outside directors are better at monitoring management.

Note 14. The 2002-2016 sample represents data in whole period. The 2007-2016 sample represents newly listed firms and firms with stage-1 mandatory appointment. The 2011-2016 sample represents newly listed firms and firms with stage-2 mandatory appointment. TWSE requires mandatory appointment of independent directors for newly listed firms since 2002. For firms listed before 2002, stage-1 mandatory appointment is applied (since 2007) for firms with market capitalization over NTD $\$ 50$ billion; stage-2 mandatory appointment is applied (since 2011) for firms with market capitalization over NTD $\$ 10$ billion; stage-3 mandatory appointment is applied (since 2014) for all publicly listed firms in Taiwan.

Note 15. Claessens, Djankov, Fan and Lang (2002), Faccio and Lang (2002), La porta, Lopez-De-Silanes, Shleifer and Vishny (2002), Wu (2009), Wu (2011) and Yeh (2005) also use market-to-book ratio as firm performance measure. ROA is also used by Keasey, Short and Watson (1994) to examine the impact of directors' ownership on firm performance.

Note 16. We use the percentage of non-executive directors' board seats as a control variable to proxy for omitted variables affecting the percentage of independent directors on the board. As compared to other directors on the board, non-executive directors share the most similarity with independent directors except that there is no $1 \%$ shareholding restriction applied on non-executive directors.

Note 17 . We address possible endogeneity issues by adding the lagged value of the performance measure as a control variable (as in Opler and Titman, 1994).

Note 18. As shown in Table 2 and 3, the positive and significant association between M/B (also P/B) and executive directors' family shareholdings is stronger than that of executive directors' shareholdings for both 2002-2016 period $(0.3030 * * *$ vs. $0.1401 * *$ for $\mathrm{M} / \mathrm{B}$ and $0.4332 * * *$ vs. $0.2216 * * *$ for $\mathrm{P} / \mathrm{B})$ and $2007-2016$ period $(0.2897 * * *$ vs. $0.2145^{* * *}$ for $\mathrm{M} / \mathrm{B}$ and $0.4110 * * *$ vs. $0.3354 * * *$ for P/B).

Note 19. As shown in Table 1, mean shareholding of executive directors' family is $0.75 \%$, as compare to $2.14 \%$ mean shareholding of executive directors for the 2002-16 sample period. 